ence Associations. Other panelists were Mary Hepburn, University of Georgia, Lewis Lipsitz, University of North Carolina, and Sheilah Mann, APSA. Members of the audience participated, actively, in the session whose key points were:

- If we are concerned about political science education, we need to "reach kids" in elementary and middle school. If they are not engaged in political life and the study of politics before high school, students are likely to be apathetic or cynical.

- If political scientists are interested in influencing the curricula, then they need to work with their local schools, school districts and state agencies. Curricula decisions are made at these levels. Moreover, social studies and civics curricula are very crowded. There are state mandates for many specialized subjects and many professional organizations and interest groups make claims for their subjects and perspectives. Hence, political science faces a great deal of competition for inclusion in precollege curricula.

- If political science departments are concerned about teacher training, as they should be, then the departments need to establish working relationships with the schools/departments of education on their campuses and to encourage their own political science students to consider teaching careers. (Teachers in the audience described the indifference of their political science faculty and advisors to their career interests.) In addition, departments should organize summer courses and workshops as inservice or continuing education for teachers. Realistically, all elementary teachers and the large majority of secondary school teachers are not political science majors. The profession should work with these teachers and make research on government and politics accessible to them and their students.

\section{Participation by Women in the 1989 APSA Meeting}

\author{
Martin Gruberg \\ University of Wisconsin-Oshkosh
}

How fared women at the 1989 APSA gathering, the 20th anniversary meeting of the Women's Caucus for Political Science? About as well as they scored in 1988, a year of advancement. (Most of the organized sections were incorporated into the Program Committee for the 1989 meeting. This made comparisons with previous years more difficult to derive.)

\begin{tabular}{|c|c|c|c|}
\hline \multicolumn{4}{|c|}{$\begin{array}{c}\text { Grand Totals (Program Committee, } \\
\text { Organized Sections and } \\
\text { APSA Committee Panels) }\end{array}$} \\
\hline Year & Total & Women & $\%$ \\
\hline \multicolumn{4}{|c|}{ Chairpersons } \\
\hline $\begin{array}{l}1984 \\
1985 \\
1986 \\
1987 \\
1988 \\
1989\end{array}$ & $\begin{array}{l}262 \\
333 \\
338 \\
485 \\
347 \\
400\end{array}$ & $\begin{array}{l}54 \\
66 \\
53 \\
79 \\
80 \\
92\end{array}$ & $\begin{array}{l}20.6 \\
19.8 \\
15.7 \\
16.3 \\
23.1 \\
23.0\end{array}$ \\
\hline \multicolumn{4}{|c|}{ Poper Givers } \\
\hline $\begin{array}{l}1984 \\
1985 \\
1986 \\
1987 \\
1988 \\
1989\end{array}$ & $\begin{array}{r}983 \\
1266 \\
1234 \\
1750 \\
1350 \\
1464\end{array}$ & $\begin{array}{l}174 \\
197 \\
239 \\
343 \\
310 \\
336\end{array}$ & $\begin{array}{l}17.7 \\
15.6 \\
19.4 \\
19.6 \\
22.6 \\
23.0\end{array}$ \\
\hline \multicolumn{4}{|c|}{ Discussants } \\
\hline $\begin{array}{l}1984 \\
1985 \\
1986 \\
1987 \\
1988 \\
1989\end{array}$ & $\begin{array}{l}347 \\
383 \\
413 \\
550 \\
435 \\
458\end{array}$ & $\begin{array}{r}64 \\
65 \\
77 \\
101 \\
92 \\
85\end{array}$ & $\begin{array}{l}18.4 \\
17.0 \\
18.6 \\
18.4 \\
21.1 \\
18.6\end{array}$ \\
\hline
\end{tabular}

As usual when women headed sections or panels, there was a greater likelihood of other women being selected for program contributions. Only seven sections were headed by women out of the 36 organized by the Program Committee (19.4\%). Yet these had women as $40 \%$ (36 of 90 ) of the chairpersons, $35.6 \%$ (116 of 326) of the paper givers, and $28.8 \%$ (30 or 104) of the 
discussants. In other words, $39.1 \%$ of the female chairs in the convention's Program Committee organized panels were found in the sections organized by women as were $34.5 \%$ of the female papergivers and $35.3 \%$ of the female discussants. (Womenchaired panels had $40.5 \%$ female papergivers and $43.6 \%$ of the discussants. These constituted $23.3 \%$ of the convention's panels yet had $41.4 \%$ of the women giving papers and $48.2 \%$ of the women serving as discussants!)

The sections with the strongest female representation were those on Law, Courts and Judicial Process; Policy Studies; Representation and Electoral Systems; Women and Politics Research; Comparative Politics-Second World; The Bill of Rights; Liberte, Equalite, Fraternite: The French Revolution at 200; and the Committee on the Status of Women.

The sections with the weakest female representation in 1989 were those on Conflict Processes, Federalism and Intergovernmental Relations, Legislative Studies, Science and Technology Studies, Comparative Politics-First World, The Civil Rights Act of 1964, Thomas Hobbes: 1588-1988, and Computer Uses.

Among the lopsidedly male panels were those on Modeling Interstate Conflict; Rational Choice and Collective Political Action; Defense Spending, Arms Control and Interstate Politics; Senate Elections: Reports from the 1988 NES State Study; Roundtable on Interest Groups and Public Policy in Pluralist Industrial Democracies; The Presidential-Congressional Nexus: New Firsts on Recruitment Issues; Public Opinion and U.S. Foreign Policy; Political Organization in Western Democracies; Rational Choice Approaches; Measuring the Effects of the Voting Rights Act; The Bill of Rights: Individual, Institutional, Minority, Majority Perspectives; and Information Intermediaries in Election Campaigns: Cross-National Comparisons.

Panels overwhelmingly female included Roundtable on Postmodernism, Critiques of Cultural Imperialism and the Identity Crisis for Feminism, Women and Bureaucracy, Women and the Law, The Impact of Women in U.S. State Legislatures, Roundtable on Feminists' Conception of Peace, and Organizing Academically: The Experi- ence of the Women's Caucus for Political Science.

The evening plenary sessions were, as usual, mostly occasions for males to be in the spotlight. (However, two of the five "Trivialists" in 1989 were women.)

\section{Women's Caucus for Political Science Celebrates 20th Anniversary}

$\mathbf{W}$ omen's Caucus for Political Science founded in 1969 celebrated its 20th Anniversary at the Atlanta Annual Meeting. To mark their anniversary, Caucus members recognized 28 "mentors." What is a mentor? A composite "portrait of a mentor" is gleaned from the many nomination letters received by the Caucus:

He encouraged me to go to graduate school in political science when most other people discouraged me, and encouraged me to do work on women and politics. She offered me a research assistantship and taught me how to do research. She played a pivotal role in the creation of Women and Politics as a major concentration within our graduate political science program. She never gave up on me, even when I was "buried" "raising two small children. He must have directed the dissertations of more women in political science than any other person in the history of the discipline. To this day she devotes time and energy helping me negotiate publication strategies and various career decisions. I am now a full professor and was selected 1988 Teacher of the Year by my College-that is my testimonial to her.

The mentors honored at the Atlanta meeting included:

Carolyn Ban, SUNY

Bernard E. Brown, CUNY Graduate Center

Philip Burgess, U.S. West Telephone Co.

Susan ]. Carroll, Rutgers University

Reo Christenson, Miami University

Anne N. Costain, University of Colorado-

Boulder

James Davies, University of Oregon

Mario Falco, Loyola University 